RESIDENT

\& FELLOW

SECTION

Section Editor

Mitchell S.V. Elkind, MD, MS

Yuebing Li, MD, PhD

Gary Clauser, MD

Donna Jenny, RN

John Castaldo, MD

Address correspondence and reprint requests to Dr. Yuebing Li, Division of Neurology,

Department of Medicine, Lehigh Valley Health Network, 1250

South Cedar Crest Boulevard, Suite 405, Allentown, PA 18103

Yuebing.Li@lvh.com

\title{
Teaching NeuroImages: \\ Falsely disappearing stroke secondary to isodense subdural hematoma
}

Figure Brain imaging

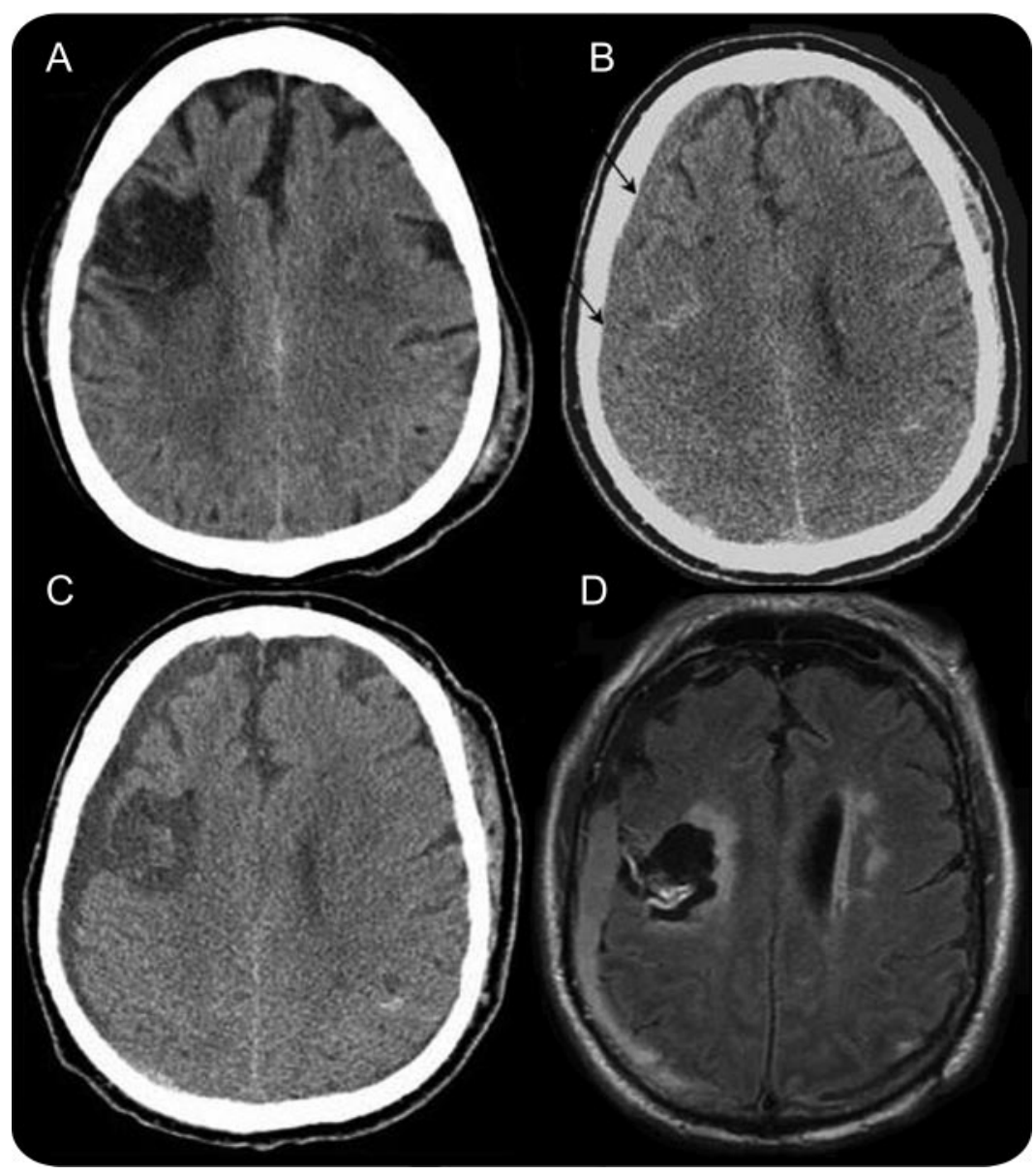

Axial CT at initial admission (A), on day 4 (B), and on day 6 (C), and (D) axial MRI showing the coexistence of an old ischemic infarction and a developing subdural hematoma.

A 59-year-old man presented with a fall. His initial CT scan showed an old infarction in the right frontal lobe (figure, A) and scattered subarachnoid hemorrhage (not shown). The infarction disappeared (figure, B) on a repeat CT on day 4 of admission, and reappeared on day 6 (figure, C). The presence of a newly developing isodense subdural hematoma was noted on the second CT (figure, B, arrows), which was verified on MRI (figure, D). Development of isodense subdural hematoma may obscure previously existent ischemic foci and should be considered especially for patients without previous imaging. 


\section{Neurology}

\section{Teaching NeuroImages: Falsely disappearing stroke secondary to isodense subdural hematoma}

Yuebing Li, Gary Clauser, Donna Jenny, et al. Neurology 2010;74;e15

DOI 10.1212/WNL.0b013e3181ccc720

\section{This information is current as of February 1, 2010}

\section{Updated Information \&} Services

Subspecialty Collections

Permissions \& Licensing

Reprints including high resolution figures, can be found at: http://n.neurology.org/content/74/5/e15.full

This article, along with others on similar topics, appears in the following collection(s):

All Cerebrovascular disease/Stroke

http://n.neurology.org/cgi/collection/all_cerebrovascular_disease_strok e

All Imaging

http://n.neurology.org/cgi/collection/all_imaging

Brain trauma

http://n.neurology.org/cgi/collection/brain_trauma

Subarachnoid hemorrhage

http://n.neurology.org/cgi/collection/subarachnoid_hemorrhage

Information about reproducing this article in parts (figures,tables) or in its entirety can be found online at:

http://www.neurology.org/about/about_the_journal\#permissions

Information about ordering reprints can be found online:

http://n.neurology.org/subscribers/advertise

Neurology ${ }^{\circledR}$ is the official journal of the American Academy of Neurology. Published continuously since 1951, it is now a weekly with 48 issues per year. Copyright . All rights reserved. Print ISSN: 0028-3878. Online ISSN: 1526-632X.

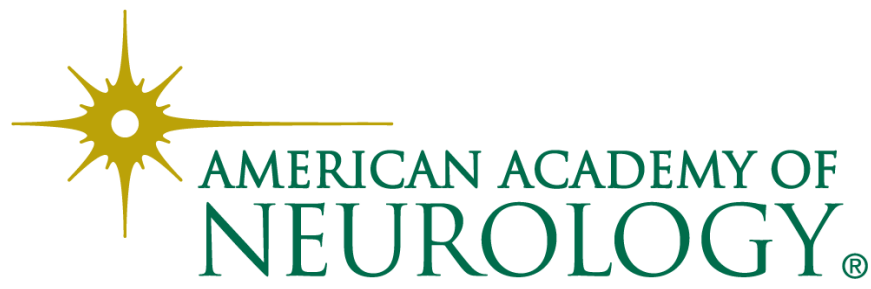

